\title{
Clonal CCND1 Gene Rearrangement
}

National Cancer Institute

\section{Source}

National Cancer Institute. Clonal CCND1 Gene Rearrangement. NCI Thesaurus. Code C27714.

A molecular abnormality indicating rearrangement of the CCND1 gene in clonal populations of either lymphocytes or lymphocyte lineage neoplastic cells. 